\title{
High school students' career decision-making pattern across parenting styles and parental attachment levels
}

\section{Fulya Cenkseven-Önder, Oğuzhan Kırdök, Erkan Işık}

Psychological Counseling \& Guidance, Çukurova University, Adana

\section{Turkey}

This research was presented at the International Congress of Counseling in İstanbul, April 2008. We would like to thank to Editor Jesús de la Fuente, Assistant Editor Juan Luís Benítez and two anonymous reviewers for their helpful comments and suggestions.

Correspondence concerning this article should be addressed to Fulya Cenkseven-Önder, Çukurova University, Faculty of Education, Psychological Counseling \& Guidance Department, Balcalı. Adana, Turkey. E-mail: fulyac@cu.edu.tr

(C) Education \& Psychology $\mathrm{I}+\mathrm{D}+\mathrm{i}$ and Editorial EOS (Spain) 


\begin{abstract}
Introduction. The purpose of this research was to investigate career decision among high school students regarding to their parenting styles (authoritative, authoritarian, indulgent, and neglectful) and parental attachment levels.

Method. With this purpose, 382 (200 females; 182 males) Turkish high school students aged 14-18 completed Career Decision Inventory, The Parenting Style Inventory and The Inventory of Parent Attachment, as measures of career decision, parenting syle and parental attachment levels, respectively. For analyzing the data one way ANOVA was performed.

Results. Results of the study demonstrated that children of more authoritative and authoritarian parents were found more decisive than the children of neglectful and indulgent parents. In terms of attachment levels, significant differences were found among all sub-scales of CDI. Furthermore, students who experienced a medium degree of attachment to their parents were found more decisive than the ones experiencing low or high degree of attachment.
\end{abstract}

Discussion. Therfore, the effects of parenting styles and parent attechment levels on career decision-making pattern have to be taken into consideration regarding to career development and career choice of adolescents. Further research should explore the explanation of career decision in terms of parenting styles and attachment levels for different gender and age groups in order to identify relevant determinants at each age level and for females and males separately.

Keywords. career decision, parenting style, parental attachment level

Received: 08/12/09 Initial Acceptance: 08/22/09 Definitive Acceptance: 01/14/10 


\section{Patrones de elección de carrera profesional entre estudian- tes de enseñanza secundaria, según los estilos de crianza parental y el nivel de apego con los padres}

\section{Resumen}

Introducción. El objetivo de esta investigación es estudiar los patrones de elección de carrera entre alumnado de secundaria en relación con los estilos de crianza parental (autoritativo, autoritario, permisivo y negligente) y los niveles de apego con los padres.

Método. Con este objetivo, 382 estudiantes turcos de secundaria (200 mujeres y 182 hombres) con edades comprendidas entre los 14 y los 18 años completaron el Inventario de Elección de la Carrera, el Inventario de Estilos de Crianza Parental y el Inventario de Apego Parental, como medidas de elección de la carrera, estilo de crianza y niveles de apego, respectivamente. Para el análisis de los datos se utilizo el análisis ANOVA.

Resultados. Los resultados del estudio muestran que los niños con padres autoritativos y autoritarios eran más decididos que aquellos con padres negligentes o permisivos. En términos de niveles de apego, se encontraron diferencias significativas entre todas la subescalas del inventario. Además, el alumnado con niveles medios de apego eran más decididos que aquellos que experimentaron niveles bajos o altos de apego.

Discusión. De acuerdo con los resultados, los efectos de los estilos de crianza y los niveles de apego en la elección de la carrera deben tenerse en consideración en relacción con el desarollo de la carrera y la elección de la misma. De la misma manera, futuras investigaciones deberían explicar la elección de la carrera en términos de estilos de crianza y niveles de apego en relación con el género y la edad para así identificar indicadores relevantes para cada nivel de edad y género.

Keywords. Elección de la carrera, estilos de crianza, niveles de apego.

Recibido: 12/08/09 Aceptación Inicial: 22/08/09 Aceptación Definitiva: 14/01/10 


\section{Introduction}

As Krumboltz and his colleagues (1976) pointed out in their social learning theory of career selection, each of us is born or adopted into a family which has learned a certain religion, has adopted certain values, and which communicates certain expectations to the new child. Hence, it is almost impossible to make a career decision completely independent from our families. Little or much, they have influence on our decisions, specifically career decisions. But the questions is, to what extent? There is a rich and diverse literature to find alternative answers to this question. Within the career literature, researchers have studied the family influence on career development (Young, Friesen, \& Pearson, 1988), career selection (Bratcher, 1982), career exploration (Blustein, 1997), development of vocational interests (Turner \& Lapan, 2002), development of vocational values (Lapan, Hinkelman, Adams, \& Turner, 1999), career expectations (Paa \& McWhirter, 2000), career orientation (O'Brien, Friedman, Tipton, \& Linn, 2000). To some extent, all of these issues are related with career decision-making process.

Besides, recent researches on family influence on career decision-making support the significance of family patterns on career development. Wolfe and Betz (2004) found that both career decision-making self efficacy and career indecisiveness were associated to the quality of parental attachment bonds. In their qualitative study, Okubo, Yeh, Lin, Fujita, and Shea (2007) found that parents' academic and career expectations influenced the career decisions of Chinese youth. In their review on the influences of the family of origin on career development, Whiston and Keller (2004) concluded that across the lifespan, both family structure variables such as parents' occupations, educational level and family process variables such as warmth, support, attachment, autonomy from parents were found to influence a large number of career constructs. Consistent with this findings, Kotrlik and Harrison (1989) asked 3858 high school students in Louisiana who had influenced their career decision-making process and the results demonstrated that parents, particularly mothers were the most influental. Parents were followed by grandparents, aunts, uncles, other relatives and siblings. In a similar study, Işık (2007) asked 705 undergraduate students from 11 faculties about the most significant person in their choice of department in higher education and 23\% reported their parents and other relatives as the influencing characters. 
The influence of the family can also be explained within the terms of parenting styles and parental attachment levels. Attachment was originally defined as the strong affective bond established between the infant and the primary caregiver (Bowlby, 1973). According to attachment theory, these bonds established during infancy continues to be effective later in that person's life (Ainsworth, 1989; Man \& Hamid, 1998). Previous research has repeatedly demonstrated that a secure attachment with parents in adolescence is associated with a better psychological well-being, less psychological distress, and greater perceived social support (Armsden \& Greenberg, 1987; Blain, Thompson, \& Whiffen, 1993; Bradford and Lyddon, 1993). Similarly, high school girls who experienced a moderate degree of attachment to their mothers were found to feel emotionally closer to their mothers and trust their mothers to assist in managing their personal affairs (O’Brien, 1996). Attachment to mother was positively associated with environmental exploration and progress in committing to career choices. Students who have greater levels of attachments to peers and to their mother were found to better commit to occupational choices and participate in career exploration process (Felsman \& Blustein, 1999). Many researchers (Lamborn, Mounts, Steinberg, Dornbusch, 1991; Steinberg, Lamborn, Darling, Mounts, \& Dornbusch, 1994; Steinberg, Lamborn, Dornbusch, \& Darling, 1992) have employed a fourfold typology of child rearing styles based on acceptance/involvement, and strictness/supervision dimensions; authoritative, authoritarian, indulgent, and neglectful. According to this typology which was also used in the present study, the acceptance/involvement dimension is related to the extent to which adolescents perceive their parents as loving, involved, and responsive. The strictness/supervision dimension has to do with parental control, monitoring, and supervision of the child. Authoritative parents are high on both dimensions; however, neglectful parents are low in both dimensions. Authoritarian parents are low on acceptance/involvement but high on strictness/supervision. Finally, indulgent parents are high on acceptance/involvement but low on strictness/supervision.

Most of the research on this specific issue is conducted with adolescents since adolescence is a period of intense exploration and deciding on a career is a key developmental task during this period (Martínez, 2007; Savickas, 2002; Super, 1990). The adolescence years are also critical for career decision-making because during these years vocational goals, interests, and values are formed (Peterson \& Gonzalez, 2000). Hence, in the current study, sample was selected from adolescents of 9th, 10th, and 11th grades in high schools. 
Examining the literature and research studies above it can surely be stated that the families have effect, wheteher positively or negatively, on people's career decisions. The level of this effect is changeable in different cultures. For Turkish culture, there is little evidence indicating the level of family factor on career decisions. Within these studies, Hamamc1 and Hamurlu (2005) found that the level of career indecision of the students whose fathers had positive attitudes was lower than those whose fathers had negative attitudes about helping their children for career development. Determining the influence of the family seems critical to understand the complexities of career development and career decision-making process. In the light of these research findings, the aim of this study was to investigate the career decision among high school students regarding to their parenting and parental attachment levels. Two reserach questions were to be looked at by this study:

1. Do high school students' career decision-making pattern vary significantly across parenting styles?

2. Do high school students' career decision-making pattern vary significantly across parent attachment levels?

\section{Method}

\section{Participants}

The participants of this study comprised 200 girls (52.4\%) and 182 boys (47.6\%), a total of 382 students in Grades 9-11 from four public high schools in Adana central province, Turkey. Their ages ranged from 14 to 18 years $(\mathrm{M}=16.08, \mathrm{SD}=.98)$. Forty-two percent were $9^{\text {th }}$ grade, $33 \%$ were $10^{\text {th }}$ grade, and $25 \%$ were $11^{\text {th }}$ grade students. A $95 \%(\alpha=0.05)$ confidence interval with a $5 \%$ probability of error was taken when calculating the sample adequecy. A vast majority of participants reported that their parents were married (92\%). Eight percent of participants' parents were divorced, and $3.7 \%$ of participants had a parent who was deceased. 


\section{Instruments}

Career Decision Inventory, CDI, (Çakır, 2004). The inventory consists of 30 items. The five categories in the career decision inventory are as follow: 1. Internal conflicts, 2. Lack of selfknowledge, 3. Lack of occupation and field knowledge, 4. Irrrational beliefs about career choice, and 5. External conflicts. As a result of the validity and reliability tests on career decision inventory, it has been found that the inventory which has been developed is appropriate in determining the level of career indecision of high school students. It has been pointed out that the inventory can be used in determing the students who are in a state of career indecision, in the secondary schools where counseling and guidance are provided. Higher scores indicate career indecision whereas lower scores indicate career decisiveness. Cronbach alpha coefficient calculated for the scale was .85 . Test-retest coefficient was .83 . The results of factor analysis yielded 5 factors with eigen values greater than 1, accounting for the $30 \%$ of the total variance (Çakır, 2004). In the present study, the Cronbach alpha coefficient was recalculated as .93 .

The Parenting Style Inventory, PSI, (Lamborn, Mounts, Steinberg, \& Darnbush, 1991). The Parenting Style Inventory (PSI), developed by Lamborn, Mounts, Steinberg and Darnbush (1991) is a 26 item multidimensional scale. The scale has three factors: acceptance/involvement, strictness/supervision, and psychological autonomy. Acceptance/involvement subscale measures the extent to which the adolescent perceives his or her parents as loving, responsive, and involved (sample item: When I have problems, I am sure that my parents will help me). The strictness/supervision subscale assesses parental monitoring and supervision of the adolescents (sample item: Does your parent permit you to go out at night during the week?). Psychological autonomy subscale assesses the extent to which parents employ noncoercive, democratic discipline and encourage the adolescents to express individuality in the family (sample item: My father and mother tell me not to argue with the elderly). Steinberg and his colleagues reported an alpha coefficient of .72 for acceptance/involvement scale; .76 for strictness/supervision scale; and .82 for psychological autonomy scale (Lamborn et al. 1991; Steinberg et al. 1992, 1994).

PSI was adapted into Turkish by Y1lmaz (2000). Cronbach alpha coefficients calculated for each subscale were .70 for acceptance/involvement, .69 for strictness/supervision, .66 
for psychological autonomy subscales. Test-retest coefficients were .82 for acceptance/involvement, .88 for strictness/supervision, and .76 for psychological autonomy.

The Inventory of Parent Attachment, IPA, (Armsden \& Greenberg, 1987). The Inventory of Parent Attachment (IPA), developed by Armsden and Greenberg (1987) and adapted into Turkish by Hortaçsu and Oral (1991), was used to determine adolescents' cognitive and affective dimensions of their attachment to their parents. The inventory consists of 28 items. The scale was rated on a 5-point scale with endpoints of never to always. Participants were instructed that if they had a different relationship with their mother and father, they should respond to the items for the parent who most influenced them. Cronbach alpha coefficients for Turkish Form was .92.

\section{Procedure and Data Analysis}

The students were asked to take part in an anonymous study examining their career decision levels, parenting styles, and parental attachment levels by completing a questionnaire packet including (a) a brief demographic questionnaire, (b) the CDI, (c) the PSI, and (d) the IPA. Researchers themselves distributed and collected the surveys during specified class sessions, and appropriate informed consent procedures were followed in collecting data.

Before the data analysis, four parenting styles were identified by assigning students based on their scores obtained from acceptance/involvement and strictness/supervision dimensions. The psychological autonomy dimension was found to be important in defining authoritativeness but less in differentiating among authoritative, authoritarian, indulgent, and neglectful parents (Lamborn et al. 1991; Steinberg et al. 1992, 1994). Consequently, scores on the acceptance/involvement and strictness/supervision dimensions were used in the present research to assign parents to one of the four groups.

The median was found 26 for acceptance/involvement and 18 for strictness/supervision dimensions. Students whose scores were above the median both on acceptance/involvement and strictness/supervision dimensions were assigned to the group of authoritative parenting style. Students whose scores were below the median both on acceptance/involvement and strictness/supervision dimensions were assigned to the group of neglectful parenting style. Students whose scores were above the median on 
acceptance/involvement and below the median on strictness/supervision dimensions were assigned to the group of indulgent parenting style. Finally, students whose scores were below the median on acceptance/involvement and above the median on strictness/supervision dimensions were assigned to the group of authoritarian parenting style.

Three hundred and eighty-two participants completed the IPA. Participants who scored at least 1 standart deviation above and below the mean on the IPA $(M=77.58$, $S D=11.45)$ were selected. Group with low parental attachment level were defined as those subjects scoring at least 1 standart deviation below the mean (66.13 and below), whereas group with mid-level of parental attachment were centre of mid and high levels (66.13 89.03), nonetheless group with high parental attachment level defined as those individuals who scored at least 1 standart deviation above the mean ( 89.03 and above). This selection process resulted in, 64 those with low parental attachment level, 252 those with mid parental attachment level, and 66 those with high parental attachment level.

After all these clasifications to analyze the gathered data, means and standard deviation distributions were investigated and one way ANOVA was performed. The analysis was carried out by using the SPSS, version 13.0.

\section{Results}

Results showed that, there were significant differences between students" "lack of selfknowledge" $\left(F_{(3,381)}=4.88, \mathrm{p}<.01\right)$, "lack of occupation and field knowledge" $\left(F_{(3,381)}=3.89\right.$, $p<.01)$ and "career decision" $\left(F_{(3,381)}=3.38, \mathrm{p}<.05\right)$ scores according to their parents' parenting styles (Table 1). Post hoc analyses to the ANOVA for career decision, lack of selfknowledge, lack of occupation and field knowledge scores consisted of conducting pairwise comparisons to find the differences among four groups of parenting styles. According to the LSD method, in the "lack of self-knowledge" scores, the results yielded significant differences between the students who perceived their parents as authoritative $(M=16.29)$ and those who perceived their parents as neglectful $(M=19.15)$ and, between the students who perceived their parents as indulgent $(M=18.86)$. Significant differences were also found between the students who perceived their parents as authoritarian $(M=16.24)$ and those who perceived their parents as 
neglectful $(M=19.15)$ and, between the students who perceived their parents as indulgent $(M=18.86)$.

Table 1. Career indecision levels of high school students according to their parenting styles

\begin{tabular}{|c|c|c|c|c|c|}
\hline & & $\mathbf{N}$ & Mean & SD & F value \\
\hline \multirow{5}{*}{ Career indecision } & Authoritative & 70 & 70.29 & 24.25 & \multirow{5}{*}{$3.38 *$} \\
\hline & Neglectful & 139 & 78.60 & 23.89 & \\
\hline & Indulgent & 97 & 79.51 & 27.00 & \\
\hline & Authoritarian & 76 & 71.26 & 22.74 & \\
\hline & Total & 382 & 75.85 & 24.79 & \\
\hline \multirow{5}{*}{ Internal conflicts } & Authoritative & 70 & 20.44 & 8.46 & \multirow{5}{*}{1.38} \\
\hline & Neglectful & 139 & 21.03 & 8.84 & \\
\hline & Indulgent & 97 & 22.72 & 8.99 & \\
\hline & Authoritarian & 76 & 20.39 & 8.67 & \\
\hline & Total & 382 & 21.23 & 8.79 & \\
\hline \multirow{5}{*}{$\begin{array}{l}\text { Lack of self- } \\
\text { knowledge }\end{array}$} & Authoritative & 70 & 16.29 & 7.24 & \multirow{5}{*}{$4.88 * *$} \\
\hline & Neglectful & 139 & 19.15 & 6.72 & \\
\hline & Indulgent & 97 & 18.86 & 7.65 & \\
\hline & Authoritarian & 76 & 16.24 & 5.72 & \\
\hline & Total & 382 & 17.97 & 6.99 & \\
\hline \multirow{5}{*}{$\begin{array}{l}\text { Lack of occupation } \\
\text { and field knowled- } \\
\text { ge }\end{array}$} & Authoritative & 70 & 17.41 & 7.11 & \multirow{5}{*}{$3.88 * *$} \\
\hline & Neglectful & 139 & 20.37 & 6.57 & \\
\hline & Indulgent & 97 & 19.75 & 7.35 & \\
\hline & Authoritarian & 76 & 18.03 & 6.52 & \\
\hline & Total & 382 & 19.21 & 6.94 & \\
\hline \multirow{5}{*}{$\begin{array}{l}\text { Irrrational beliefs } \\
\text { about career choice }\end{array}$} & Authoritative & 70 & 7.61 & 3.49 & \multirow{5}{*}{1.44} \\
\hline & Neglectful & 139 & 8.53 & 3.55 & \\
\hline & Indulgent & 97 & 8.62 & 3.91 & \\
\hline & Authoritarian & 76 & 8.02 & 3.35 & \\
\hline & Total & 382 & 8.28 & 3.60 & \\
\hline \multirow{5}{*}{ External conflicts } & Authoritative & 70 & 8.54 & 3.33 & \multirow{5}{*}{1.89} \\
\hline & Neglectful & 139 & 9.52 & 4.21 & \\
\hline & Indulgent & 97 & 9.57 & 3.86 & \\
\hline & Authoritarian & 76 & 8.58 & 3.99 & \\
\hline & Total & 382 & 9.17 & 3.94 & \\
\hline
\end{tabular}

In the "lack of occupation and field knowledge" sub-scale scores, significant differences were found between the students who perceived their parents as authoritative $(M=17.41)$ and those who perceived their parents as neglectful $(M=20.37)$ and, between the students who perceived their parents as indulgent $(M=19.75)$. Also, there were significant difference between the students who perceived their parents as authoritarian $(M=18.03)$ and neglectful $(M=20.37)$. Using the LSD method, as to career decision scores, the results yielded 
significant differences between the students who perceived their parents as authoritative $(M=70.29)$ and those who perceived their parents as neglectful $(M=78.60)$ and, between the students who perceived their parents as indulgent $(M=79.51)$. Significant differences were also found in the students who perceived their parents as authoritarian $(M=71.26)$ and those who perceived their parents as neglectful $(M=78.60)$ and, between the students who perceived their parents as indulgent $(M=79.51)$.

Table 2. Career indecision levels of high school students according to the level of their parental attachment

\begin{tabular}{|c|c|c|c|c|c|}
\hline & Parental attachment levels & $\mathbf{N}$ & Mean & SD & F value \\
\hline \multirow{4}{*}{ Career indecision } & Parental attachment - low & 64 & 82.81 & 25.90 & \multirow{4}{*}{$4.89 * *$} \\
\hline & Parental attachment - medium & 252 & 73.11 & 25.13 & \\
\hline & Parental attachment-high & 66 & 79.56 & 20.58 & \\
\hline & Total & 382 & 75.85 & 24.79 & \\
\hline \multirow{4}{*}{ Internal conflicts } & Parental attachment - low & 64 & 23.15 & 9.52 & \multirow{4}{*}{$3.27 *$} \\
\hline & Parental attachment - medium & 252 & 20.42 & 8.73 & \\
\hline & Parental attachment-high & 66 & 22.45 & 7.96 & \\
\hline & Total & 382 & 21.23 & 8.79 & \\
\hline \multirow{4}{*}{$\begin{array}{l}\text { Lack of self- } \\
\text { knowledge }\end{array}$} & Parental attachment - low & 64 & 19.25 & 7.23 & \multirow{4}{*}{$3.60 *$} \\
\hline & Parental attachment - medium & 252 & 17.29 & 7.05 & \\
\hline & Parental attachment-high & 66 & 19.35 & 6.19 & \\
\hline & Total & 382 & 17.97 & 6.99 & \\
\hline \multirow{4}{*}{$\begin{array}{l}\text { Lack of occupation } \\
\text { and field knowledge }\end{array}$} & Parental attachment - low & 64 & 20.87 & 6.66 & \multirow{4}{*}{$3.25^{*}$} \\
\hline & Parental attachment - medium & 252 & 18.59 & 7.08 & \\
\hline & Parental attachment-high & 66 & 19.95 & 6.41 & \\
\hline & Total & 382 & 19.21 & 6.94 & \\
\hline \multirow{4}{*}{$\begin{array}{l}\text { Irrrational beliefs } \\
\text { about career choice }\end{array}$} & Parental attachment - low & 64 & 9.25 & 3.75 & \multirow{4}{*}{$4.73 * *$} \\
\hline & Parental attachment - medium & 252 & 7.89 & 3.60 & \\
\hline & Parental attachment -high & 66 & 8.84 & 3.23 & \\
\hline & Total & 382 & 8.28 & 3.60 & \\
\hline \multirow{4}{*}{ External conflicts } & Parental attachment - low & 64 & 10.30 & 3.92 & \multirow{4}{*}{$3.19 *$} \\
\hline & Parental attachment - medium & 252 & 8.93 & 3.93 & \\
\hline & Parental attachment -high & 66 & 8.97 & 3.88 & \\
\hline & Total & 382 & 99.17 & 3.94 & \\
\hline
\end{tabular}

${ }^{*} \mathrm{p}<.05,{ }^{* *} \mathrm{p}<.01$

As seen in the Table 2, results of one way ANOVA demonstrated that, there were significant differences between parental attachment levels in terms of students' levels of "internal conflicts" $\left(F_{(2,381)}=3.27, p<.05\right)$ "lack of self-knowledge" $\left(F_{(2,381)}=3.60, p<.05\right)$ "lack of occupation and field knowledge" $\left(F_{(2,381)}=3.25, p<.05\right)$ "irrrational beliefs about career choice" $\left(F_{(2,381)}=4.73, p<.01\right)$ "external conflicts" $\left(F_{(2,381)}=3.19, \mathrm{p}<.05\right)$ and "career decision" $\left(F_{(2,381)}=4.89, p<.01\right)$. To elucidate the exact source of the difference, the LSD 
results were scrutinized. LSD results indicated that, in career decision and its all sub-scales, there were significant differences between the students having low level of parental attachment and those having avarage level of parental attachment $(p<.05)$. Also, in the "lack of self-knowledge" sub-scale, significant differences were found between the students having average level of parental attachment and those having high level of parental attachment $(p<.05)$. However, there were no significant differences between the students having high level of parental attachment and the students having low and average parental attachment in terms of their "internal conflicts", "lack of occupation and field knowledge", "irrrational beliefs about career choice", "external conflicts" and "career decision" scores.

\section{Discussion}

In lack of self-knowledge, lack of occupation and field knowledge sub-scales, and also in total scores of CDI, students coming from more authoritative and authoritarian families were found more decisive than the ones coming from neglectful and indulgent families. These findings would be due to the fact that authoritative families show their love to their children while controling and directing them (Lamborn et al. 1991). Consistent with these results, former research results has also showed that authoritative style is positively associated with exploration of self and environment in adolescence (Kracke, 1997). This condition would have contributed to student's knowledge of themselves and their career decisions. Authoritative parents show warmth toward and interest in their adolescents as well as laying down rules. They should stimulate the adolescent to search for educational and vocational information, in order to foster their autonomies (Vignoli, Croity-Belz, Chapeland, Fillipis \& Garcia, 2005). Furthermore, neglectful and indulgent families do not support their children in their career decisions. In related literature, similar results were found. For instance, neglectful parents who showed no interest in their adolescents' school and career plans, and do not lay down rules, would discourage their adolescents' exploratory activities. The more neglectful the families were, the less frequently did adolescents request information from family members and the less diversified were their visits to career counseling centers and talks with professionals (Eigen, Hartman, \& Hartman, 1987; Vignoli et al., 2005).

An unexpected result was that children of authoritarian parents were found more decisive when compared with the children of neglectful and indulgent parents. This may have 
resulted due to the fact that authoritarian parents make choices on behalf of their children and the children from such families accept their parents' choices as their own. According to Marcia's identity status theory, children from authoritarian families are in foreclosure identity status and do not experience decision (Senemoğlu, 2007).

In internal and external conflicts, and irrational beliefs about career choice sub-scales of CDI, children of more authoritative and authoritarian parents were found more decisive than the ones from neglectful and indulgent families. However, the levels were not at significant levels. Since the perceptions of the individuals are more effective than the situation itself in terms of cognitive process such as irrational beliefs and conflicts (Beck, 1979; Ellis ve Harper, 1975; Beck, 1995), other factors rather than the parenting syles would have been more effective on these dimensions of indecisiveness. Factors which were found effective on career indecision are anxiety (Hartman \& Fuqua, 1983; Jones, 1989), personality (Cohen, Chartland \& Jowdy, 1995; Newman, Gray \& Fuqua, 1999), and self-efficacy (Taylor \& Betz, 1983).

In all sub-scales of CDI, students who experienced a medium degree of attachment to their parents were found more decisive than the ones experiencing low or high degree of attachment. There are findings that a moderate degree of attachment is a more healthy condition for the individuals to develop in parent-child relationships. For example, Felsman and Blustein (1999) determined that individuals who maintain a moderate attachment to mother were more likely to have explored their social environment and to have progressed in committing to career choices. Likewise, high school female students who experienced a moderate degree of attachment to their mothers, relied on their mothers to assist in managing their personal affairs, felt emotionally close to their mothers, and shared similar beliefs and attitudes with their mothers and fathers were found to possess very strong career self-efficacy beliefs (O'Brien, 1996). Further research should explore the explanation of career decision in terms of parenting styles and attachment levels for different gender and age groups in order to identify relevant determinants at each age level and for females and males separately. 


\section{References}

Albion, M.J. \& Fogarty, G.J. (2002). Factors influencing career decision making in adolescents and adults. Journal of Career Assessment, 10, 91-126.

Ainsworth, M. D. S. (1989). Attachments beyond infancy. American Psychologist, 44, 709716.

Armsden, G., \& Greenberg, M. (1987). The inventory of parent and peer attachment: Individual differences and their relationship to psychological well-being in adolescence. Journal of Youth Adolescence, 16, 427-454.

Beck, A.T. (1979). Cognitive therapy and the emotional disorders. Boston: Merdian Books.

Beck, J.S. (1995). Cognitive therapy. Basics and beyond. New York: Guilfort Press.

Blain, M., Thompson, J., \& Whiffen, V. (1993). Attachment and perceived social support in late adolescence: The interaction between working models of self and others. Journal of Adolescent Research, 8, 226-241.

Blustein, D. L. (1997). A context-rich perspective of career exploration across the life roles. The Career Development Quarterly, 45, 260-274.

Bowlby, J. (1973). Attachment and loss, vol 2. Separation: Anxiety and anger. New York: Basic Books.

Bradford, E., \& Lyddon, W. J. (1993). Current parental attachment: Its relation to perceived psychological distress and relationship satisfaction in college students. Journal of College Student Development, 34, 256-272.

Bratcher, W. E. (1982). The Influence of the family on career selection: A family systems perspective. Personnel and Guidance Journal, 61, 87-91.

Çakır, M. A. (2004). The development of Career Decision Inventory. Ankara University Journal of Faculty of Educational Sciences, 37, 1-14.

Cohen, C.R., Chartland, J.M. \& Jowdy, D.P. (1995). Relationships between career indecision subtypes and ego identity development. Journal of Counseling Psychology, 42, 440447.

Eigen, C. A., Hartman, B. W., \& Hartman, P. T. (1987). Relations between family interactive patterns and career indecision. Psychological Reports, 60, 87-94.

Ellis, A., \& Harper, R. A. (1975). A new guide to rational living. Oxford, England: PrenticeHall.

Felsman, D.E. \& Blustein, D.L. (1999). The role of peer relatedness in late adolescent career development. Journal of Vocational Behavior, 54, 279-295. 
Hamamc1, Z., Hamurlu, M. K. (2005). Relationship between level of knowledge and attitudes of parents about helping their children for career development and career indecision of their children. İnönü Üniversitesi Eğitim Fakültesi Dergisi, 6, 55-69.

Hartman, B.W., \& Fuqua, D.R. (1983). The predictive potential of The Career Decision Scala in identifying cronic career indecision. Vocational Guidance Quarterley, 33, 231-240.

Hortaçsu, N., \& Oral, A. (1991). Factors affecting relationships of Turkish adolescents with parents and same-sex friends. Journal of Social Psychology, 131(3), 413-427.

Işık, E. (2007). Perceptions and expectations of the university students from the career counseling services given at their university, XVI. National educational sciences congress book. (pp. 719-727). Ankara: Detay Publications.

Jones, L.K. (1989). Measuring a three-dimensional construct of career indecision. Journal of Counseling Psychology, 36, 477-486.

Kotrlik, J.W.,\& Harrison, B. C. (1989). Career decision patterns of high school seniors in Louisiana. Journal of Vocational Education, 14, 47-65.

Kracke, B. (1997). Parental behaviors and adolescents' career exploration. Career Development Quarterly, 45(4), 341-350.

Krumboltz, J. D., Mitchell, A. M., \& Jones, G. B. (1976). A Social Learning Theory of career selection. The Counseling Psychologist, 6, 71-81.

Lamborn, S. D., Mounts, N. S., Steinberg, L., \& Dornbusch, S. M. (1991). Patterns of competence and adjustment among adolescents from authoritative, authoritarian, indulgent, and neglectful families. Child Development, 62, 1049-1065.

Lapan, R. T., Hinkelman, J. M., Adams, A., \& Turner, S. (1999). Understanding rural adolescents' interests, values, and efficacy expectations. Journal of Career Development, 26(2), 107-124.

Lawrence, J., Poole, P., \& Diener, S. (2003). Critical factors in career decision making for women medical graduates. Medical Education, 37, 319-327.

Luzzo, D. A., McWhirter, E. H., \& Hutcheson, K. G. (1997). Evaluating career decisionmaking factors associated with employment among first-year college students. Journal of College Student Development, 38, 166-172.

Man, K., \& Hamid, P. N. (1998). The relationship between attachment prototypes, selfesteem, loneliness, and casual attributions in Chinese trainee teachers. Personality and Individual Differences, 24, 357-371. 
Martínez, J. M. (2007). Vocational and professional guidance through the Self-Directed Search (SDS). Electronic Journal of Research in Educational Psychology, 11, 5(1), 233-258.

Newman, J.L., Gray, E.A. \& Fuqua, D.R. (1999). The relation of career indecision to personality dimensions of the California Psychological Inventory. Journal of Vocational Behavior, 54, 174-187.

O’Brien, K. M. (1996). The influence of psychological separation and parental attachment on the career development of adolescent women. Journal of Vocational Behavior, 48, 257-274.

O’Brien, K., Friedman, S. C., Tipton, L. C., \& Linn, S. G. (2000). Attachment, separation, and women's vocational development: A longitudinal analysis. Journal of Counseling Psychology, 47, 301-315.

Okubo, Y., Yeh, C. J., Lin, P., Fujita, K., \& Shea, M. (2007). The career decision making process of Chinese American youth. Journal of Counseling \& Development, 85, 440449.

Paa, H. K., \& McWhirter, E. H. (2000). Perceived influences on high school students' current career expectations. The Career Development Quarterly, 49, 29-44.

Peterson, N., \& Gonzalez, R. C. (2000). The role of work in people's lives: Applied career counseling and vocational psychology. Belmont, CA: Wadsworth/Thomson Learning.

Savickas, M. L. (2002). Career construction: A developmental theory of vocational behavior. In D. Brown \& Associates (Eds.), Career choice and development (4 ${ }^{\text {th }}$ ed., pp. 149205). San Francisco: Jossey-Bass.

Senemoğlu, N. (2007). Development, learning, and teaching: From theory to practice. Ankara: Gönül Yayıncılık.

Steinberg, L., Lamborn, S. D., Darling, N., Mounts, N. S., \& Dornbusch, S. M. (1994). Overtime changes in adjustment and competence among adolescents from authoritative, authoritarian, indulgent, and neglectful families. Child Development, 65, 754-770.

Steinberg, L., Lamborn, S. D., Dornbusch, S. M., \& Darling, N. (1992). Impact of parenting practices on adolescent achievement authoritative parenting, school involvement, and encouragement to succeed. Child Development, 63, 1266-1281.

Super, D. E. (1990). A life-span, life-space approach to career development. In D. Brown \& L. Brooks (Eds.), Career choice and development: Applying contemporary theories to practice ( $2^{\text {nd }}$ ed., pp. 197-261). San Francisco: Jossey-Bass. 
Taylor, K.M. \& Betz, N.E. (1983). Application of self-efficacy theory to the understanding and treatment of career indecision. Journal of Vocational Behavior, 22, 63-81

Turner, S., \& Lapan, R. T. (2002). Career self-efficacy and perceptions of parent support in adolescent career development. The Career Development Quarterly, 51, 44-55.

Vignoli, E., Croity-Belz, S., Chapeland, V., Fillipis, A. \& Garcia, M. (2005). Career exploration in adolescents: The role of anxiety, attachment, and parenting style. Journal of Vocational Behavior, 67, 153-168.

Whiston, S. C., Keller, B. K. (2004). The influences of the family of origin on career development: A review and analysis. The Counseling Psychologist, 32, 493-568.

Wolfe, J. B., \& Betz, N. E. (2004). The relationship of attachment variables to career decision-making self-efficacy and fear commitment. The Career Development Quarterly, 52, 363-369.

Y1lmaz, A. (2000). Relationships between marital adjustment, child perception of parenting style and children, adolescents and young adults academic achievement and selfperceptions. Unpublished Doctoral Dissertation, Ankara: Hacettepe University Institute of Social Sciences.

Young, R. A., Friesen, J. D., \& Pearson, H. M. (1988). Activities and interpersonal relations as dimensions of behavior in the career development of adolescents. Youth and Society, 20, 29- 45 . 
Fulya Cenkseven-Önder et al.

[This page intentionally left blank] 